Shakespeare

\title{
Introduction: Visions of Rome in Shakespeare
}

\section{Domenico Lovascio}

To cite this article: Domenico Lovascio (2019): Introduction: Visions of Rome in Shakespeare, Shakespeare, DOI: 10.1080/17450918.2019.1649301

To link to this article: https://doi.org/10.1080/17450918.2019.1649301

Published online: 21 Aug 2019.

Submit your article to this journal $\pi$

Џ Article views: 24

Q View related articles $₫$

View Crossmark data $־$ 


\title{
Introduction: Visions of Rome in Shakespeare
}

\author{
Domenico Lovascio \\ Dipartimento di Lingue e culture moderne, Università degli Studi di Genova, Genoa, Italy
}

\begin{abstract}
This introduction draws attention to the fact that Shakespeare's Roman world, while having a distinct identity largely built on the characters' striving to achieve and maintain virtus, is simultaneously inflected with manifold different attitudes towards a broad range of issues that are open to a wide array of possible "visions" both inside the dramatic world and outside of it, in the realm of criticism. The introduction then quickly surveys the main critical contributions concerning Shakespeare's engagement with romanitas, especially focusing on the upsurge of studies about Shakespeare and Rome that has characterized the past few years.
\end{abstract}

\section{KEYWORDS}

Romanitas; Latin culture; Roman history; politics; appropriation

William Shakespeare's interest in romanitas spanned his entire career. References to and reworkings of Roman history, literature and culture are disseminated throughout his canon, which hosts as many as six works that can be categorized to varying degrees as "Roman": Titus Andronicus (1584-94), Lucrece (1594), Julius Caesar (1599), Antony and Cleopatra (1606-07), Coriolanus (1607-09) and Cymbeline (1609-11). ${ }^{1}$ If one were willing slightly to stretch the inclusion criteria, this group may even be susceptible of increasing to seven units on the grounds that Troilus and Cressida (1601-03), albeit Greek in setting, is in fact widely informed by the myth of the Trojan origins of the Britons and the idea of a north-westward translatio imperii from Troy through Rome to Britain via the emigration of Brute, Aeneas's legendary great-grandson, first narrated in the ninth-century Historia Brittonum but more widely popularized by Geoffrey of Monmouth's twelfth-century Historia Regum Britanniae.

The events of Roman history and the products of Latin culture were a major influence on Shakespeare's imagination, their intrinsic dramatic potential and fascinating inconsistencies proving to be a key constituent in his craft and art. In fact, Shakespeare's profound and ever-evolving exploration of Rome's contradictory duplicity is possibly the highest instantiation of the early modern engagement with the incendiary potentialities inherent in any creative negotiations with and appropriations of the Roman past in literature and culture. Each of Shakespeare's Roman works offers a many-sided, engrossing but sometimes even disturbing mixture of opposing tendencies and forces between history and fiction, with the past and the present constantly re-activating and remoulding each other in a riveting game of distorted reflections.

The title of this special issue is "Shakespeare: Visions of Rome". The rationale behind the use of the plural should be immediately apparent to anyone who has seen or read at least a couple of Shakespeare's Roman plays. While in many respects Shakespeare's Roman world displays consistency and coherence - especially when taking into account the tragedies that are mostly based on Thomas North's Plutarch (i.e., Julius Caesar, Antony and Cleopatra and Coriolanus) - that same world is simultaneously inflected with manifold different attitudes towards a broad range of issues that are 
consequently open to many possible interpretations. This is partly due to the fact that Shakespeare did not merely draw upon Plutarch but in fact perused and absorbed a highly diverse array of classical texts as well as early modern texts mediating classical culture, which he generally reworked with peculiar flexibility and an attitude to different viewpoints that it might be appropriate to label pluralistic.

Whereas Shakespeare's Rome clearly exhibits a distinct identity that is not simply predicated on the symbolic meanings attached to the signifier "Rome" but is largely built on a set of values that are regarded as essential in striving to achieve and maintain virtus (albeit often marred by envy, rivalry and greed), it can be seen at the same time as a brilliant showcase of different philosophical stances, ranging from Stoicism to Platonism to Epicureanism; of different forms of government, ranging from monarchy to republic to empire; of different forms of political constitution, ranging from oligarchy to democracy to tyranny; but also of different ways to wield power, different rhetorical styles, different conceptions of time and space, different ways to see and seek death, and especially different ways to see Rome, fellow Romans and the world.

There is quite a major leap, for instance, from the eminently local, even provincial view of Rome and the world expressed by Coriolanus to the staggeringly cosmopolitan perspective that informs Antony and Cleopatra - the way in which characters see Rome and the world often depending on how they view each other. In Julius Caesar, Cassius wishes "that noble Brutus had his eyes" (1.2.64) not so much to have him look within himself and "turn / [His] hidden worthiness into [his] eye, / That [he] might see [his] shadow" (1.2.58-60), as eventually to have him share Cassius's own vision of the current political situation in Rome, which he feels is in need of correcting; in Antony and Cleopatra, Philo invites Demetrius (and, by extension, the theatrical audience) to "Behold and see" (1.1.13) not only what the lovers are up to in Egypt but especially what Antony's vision of Rome and of its foundational ideals has become and to what consequences this may lead in terms of the future of Rome itself; in Coriolanus, the title character is doomed because of his impossibility to share his countrymen's vision of Rome and politics, and his refusal to expose the scars he has obtained during years of fierce and dangerous battles to the view of the people seems particularly difficult to accept for them, because it prevents them from projecting on those scars the vision of a bloody, glorious past turning into a safe, peaceful future. Further examples may be produced, the point being that while Shakespeare's Roman world undoubtedly has its own distinct identity, at the same time there cannot be said to exist a single, univocal vision encompassing it as a whole: opposed gazes come into conflict; patricians and plebeians, men and women, winners and losers view events and situations in much different lights; often, the Rome that characters think they see does not correspond to what Rome actually is, and it thereby does not seem coincidental that Brutus's most disastrous mistake in Julius Caesar is to think that there can be only one vision of Rome available to the people, that is his own.

Unsurprisingly, such a plurality of visions of Rome, incorporating so many diverse, and frequently conflicting, perspectives (often made even more intricate by the fact that Rome was now the papal see, which made any treatment of Rome potentially ambivalent and heated from a religious standpoint) becomes even more complicated when the outside gaze of the critics sets out to scrutinize Shakespeare's Roman works in order to unravel what they may suggest in terms of politics, philosophy, rhetoric, gender, race, identity, otherness and so on. Shakespeare himself ends up being viewed each time not merely as a playmaker and a poet but also - and, perhaps, even primarily in some scholars' eyes - as a historian, a philosopher, a psychologist or a political thinker presciently anticipating future developments in the most disparate fields of human knowledge.

The first scholar to tackle the Roman plays as a coherent group in a book-length study (though limiting his analysis to Julius Caesar, Antony and Cleopatra and Coriolanus) was M.W. MacCallum in his seminal Shakespeare's Roman Plays and Their Background over a hundred years ago. And while critical interest in Shakespeare's engagement with romanitas and classical antiquity cannot be said to have ever been really as "fashionable" as other areas of scholarly interest in the twentieth century, it certainly never wavered in the decades after World War II, with various scholars following 
in MacCallum's steps, namely T.J.B. Spencer and J. Leeds Barroll in the 1950s; Maurice Charney and Derek Traversi in the 1960s; J.L. Simmons, Paul A. Cantor, Michael Platt, George K. Hunter, John Wilders and David C. Green in the 1970s; Robert S. Miola, Paul N. Siegel, Alexander Leggatt and Vivian Thomas in the 1980s; Charles and Michelle Martindale, Charles Wells, Geoffrey Miles and Coppélia Kahn in the 1990s. ${ }^{2}$

Such an impressive list - which only includes sweeping treatments of Shakespeare and Rome and disregards studies of individual works - is, however, outshone (at least in numerical terms) by the exponential growth that studies in the same vein have experienced after the turn of the millennium, an upsurge that partakes of a renewed and vigorous scholarly interest in the reception of the Roman past in early modern English literature and culture at large (Lovascio and Hopkins 12). As a matter of fact, the first fifteen years of the twenty-first century have witnessed the publication of edited collections by Maria Del Sapio Garbero, Sarah Hatchuel and Nathalie Vienne-Guerrin, and Del Sapio Garbero, Nancy Isenberg and Maddalena Pennacchia, as well as monographs by Barbara L. Parker, Warren Chernaik, Pennacchia, Colin Burrow, Lisa S. Starks-Estes and Paul Innes, who have all tackled Shakespeare's Roman world from different perspectives. ${ }^{3}$

Such a proliferation of critical treatments of Shakespeare's Rome has further spiked up in the last three years, with the publication of edited collections by Del Sapio Garbero and Daniela Guardamagna - both springing from the series of coordinated events devoted to Shakespeare and the resonance of ancient Rome throughout his oeuvre held in Rome from 7 to 20 April 2016 under the collective title Shakespeare 2016: Memoria di Roma to celebrate the 400th anniversary of Shakespeare's death - a thematic issue of Shakespeare Survey on "Shakespeare and Rome" (2016) and a special issue of the journal Memoria di Shakespeare edited by Rosy Colombo entirely devoted to Antony and Cleopatra, as well as monographs by Cantor, Patrick Gray and Jonathan Bate. ${ }^{4}$ To these, forthcoming books by Graham Holderness and Maria Del Sapio Garbero should also be added. Such an unceasing interest in Shakespeare's fraught engagement with romanitas has even met institutional concretization in a teaching context with the establishment of the Shakespeare's Rome International Summer School (SRISS) at Università di Roma Tre. The SRISS was founded in 2017 by Maria Del Sapio Garbero and is now directed by Maddalena Pennacchia. It is now in its third year of activity and keeps attracting graduate and postgraduate students, as well as early-career academics and high-school teachers from all around the world.

Such a growing concern with all things Roman in Shakespeare studies is possibly at least partly dependent on the delicate political events and changes that the United Kingdom, the USA and Europe have been going through over the past few years - it is still unclear at the moment of writing under what terms the UK will leave the European Union - which have simultaneously prompted a massive rediscovery of Shakespeare's Roman plays on stage: for example, the Royal Shakespeare Company staged a "Roman season" in Stratford-upon-Avon in 2017, while performances of Julius Caesar and Coriolanus recently multiplied on both sides of the Atlantic, with some American productions even polemically including pictures of Donald Trump, the then President of the USA, in theatre programmes of productions of Julius Caesar.

This special issue of Shakespeare therefore seeks to provide a timely contribution to this area of studies by offering a diverse range of articles providing ample demonstration of the variety and wealth of visions of Rome in Shakespeare's works. Matthew Williamson explores the culinary landscapes of Antony and Cleopatra, arguing that food is deployed in the play as a means to conceptualize the perils and possibilities of colonial expansion by highlighting the uneasy temporality of these issues, at a time when England itself was emerging as a nascent imperial power. By emphasizing the interrelation of consumption and distribution in the text, Williamson contends that the play's various acts of abstinence and excess can only be understood by situating them within a contemporary understanding of Rome's transition from want to plenty.

The importance of gesture in Titus Andronicus, a play that seems to exhibit a quasi-pathological fixation on the manual, is the main concern of Stephanie L. Pope's article. Considering both seventeenth-century theories that saw gesture as a potential remedy for the confusion visited on humankind 
at Babel and contemporary attitudes towards actio - the fifth canon of rhetoric, lauded by both Cicero and Quintilian as the most vital element of successful oratory - Pope interrogates Titus's conflicted attitudes towards the classical past and suggests that Titus's injudicious deployment of classical literary precedent at the play's close is a corollary of his inability, after severing his hand, to perform actio effectively.

In an investigation of the role of theatrical properties in Shakespeare's Roman plays, Maddalena Pennacchia argues that they often acquire an intermedial quality, that is, a capacity of drawing attention to themselves as the locus of transit of information in a communication system that was rapidly growing in size and complexity in the Renaissance. Tablets, rolls and letters, painted cloths and embroidery samples, for instance, reference different media and arts that relate to each other, thus highlighting both the hypermedial nature of the stage and the many channels through which classical culture was transferred from antiquity to the Renaissance.

Cristina Paravano concludes this special issue by exploring how Shakespeare developed his reenvisioning of the myth of the Roman empire and its civilization through his recourse to food images in Titus Andronicus and Cymbeline. Both plays, suggest Paravano, are punctuated by references to foodstuffs, animals and mutilated body parts, while at the same time featuring moments of conviviality. Paravano's argument is twofold; on the one hand, she finds that in Titus Andronicus the recurring bodily parts are the epitome of the fragmentation of the body politic of "headless Rome" (1.1.186) and of the disintegration of the traditional Roman values and principles under the threat of barbaric invasion. On the other hand, she contends that in Cymbeline, set at the time of Emperor Augustus, Shakespeare seems to take stock of his previous works, many of which powerfully resonate in this play, thereby shaping an ambiguous and fascinating image of Rome.

\section{Notes}

1. Credit for having been the first to discuss all six Roman works together as a group must be given to Miola.

2. As regards monographs, Charney, Traversi, Simmons, Green and Miles follow MacCallum in only treating Julius Caesar, Antony and Cleopatra and Coriolanus; Cantor (Shakespeare's Rome) limits his discussion to Antony and Cleopatra and Coriolanus; Platt includes Lucrece but leave Titus Andronicus out; Siegel, Leggatt and Wilders all consider the Roman plays (thus excluding Lucrece) in relation to the English chronicle plays, with Leggatt and Wilders, however, only tackling Julius Caesar, Antony and Cleopatra and Coriolanus; Thomas adds Titus Andronicus to the three Plutarchan plays, thereby leaving Lucrece and Cymbeline out; the Martindales and Kahn follow Miola in discussing all six Roman works together; Wells's is a study of Roman values in Shakespeare's work more generally.

3. As to monographs, Parker does not treat Cymbeline in her study; Pennacchia and Innes restrict their focus to drama, thus leaving Lucrece out; Chernaik, Burrow and Starks-Estes follow Miola and Kahn in treating all six Roman works together.

4. Cantor (Shakespeare's Roman Trilogy) limits his discussion to the three Plutarchan plays; Gray especially treats Julius Caesar and Antony and Cleopatra, with frequent references to Coriolanus.

\section{Disclosure statement}

No potential conflict of interest was reported by the author.

\section{ORCID}

Domenico Lovascio (D) http://orcid.org/0000-0001-9379-2040

\section{Works cited}

Barroll, J. Leeds. "Shakespeare and Roman History." The Modern Language Review 53 (1958): 327-43. Print. Bate, Jonathan. How the Classics Made Shakespeare. Princeton: Princeton University Press, 2019. Print. Burrow, Colin. Shakespeare \& Classical Antiquity. Oxford: Oxford University Press, 2013. Print. 
Cantor, Paul A. Shakespeare's Roman Trilogy: The Twilight of the Ancient World. Chicago: University of Chicago Press, 2017. Print.

Cantor, Paul A. Shakespeare's Rome: Republic and Empire. Ithaca: Cornell University Press, 1976. Print.

Charney, Maurice. Shakespeare's Roman Plays: The Function of Imagery in the Drama. Cambridge, MA: Harvard University Press, 1961. Print.

Chernaik, Warren. The Myth of Rome in Shakespeare and His Contemporaries. Cambridge: Cambridge University Press, 2011. Print.

Colombo, Rosy, ed. Mapping Antony and Cleopatra: Permanence and Mobility. Special issue. Memoria di Shakespeare 4 (2017). Online.

Del Sapio Garbero, Maria, ed. Identity, Otherness and Empire in Shakespeare's Rome. Farnham: Ashgate, 2009. Print.

Del Sapio Garbero, Maria, ed. Rome in Shakespeare's World. Roma: Storia e Letteratura, 2018. Print.

Del Sapio Garbero, Maria. Shakespeare's Ruins and Myth of Rome. London: Routledge, forthcoming. Print.

Del Sapio Garbero, Maria, Nancy Isenberg, and Maddalena Pennacchia, eds. Questioning Bodies in Shakespeare's Rome. Göttingen: V\&R Unipress, 2010. Print.

Gray, Patrick. Shakespeare and the Fall of the Roman Republic: Selfhood, Stoicism and Civil War. Edinburgh: Edinburgh University Press, 2018. Print.

Green, David C. Plutarch Revisited: A Study of Shakespeare's Last Roman Tragedies and Their Source. Salzburg: Institut fur Anglistik und Amerikanistik, 1979. Print.

Guardamagna, Daniela, ed. Roman Shakespeare: Intersecting Times, Spaces, Languages. Bern: Peter Lang, 2018. Print.

Hatchuel, Sarah, and Nathalie Vienne-Guerrin, eds. Shakespeare on Screen: The Roman Plays. Mont Saint Aignan: Publications des Universités de Rouen et du Havre, 2009. Print.

Holderness, Graham. Shakespeare and Rome. London: Routledge, forthcoming. Print.

Holland, Peter, ed. Shakespeare and Rome. Thematic issue. Shakespeare Survey 69 (2016). Print.

Hunter, George K. “A Roman Thought: Renaissance Attitudes to History Exemplified in Shakespeare and Jonson.” An English Miscellany: Presented to W.S. Mackie, ed. Brian S. Lee. Cape Town: Oxford University Press, 1977. 93-118. Print.

Innes, Paul. Shakespeare's Roman Plays. London: Palgrave, 2015. Print.

Kahn, Coppélia. Roman Shakespeare: Warriors, Wounds and Women. London: Routledge, 1997. Print.

Leggatt, Alexander. Shakespeare's Political Drama: The History Plays and the Roman Plays. London: Routledge, 1988. Print.

Lovascio, Domenico, and Lisa Hopkins. "Introduction: Ancient Rome and English Renaissance Drama." The Uses of Rome in English Renaissance Drama 29.2 (2016): 9-19.

MacCallum, M.W. Shakespeare's Roman Plays and Their Background. London: Macmillan, 1910. Print.

Martindale, Charles, and Michelle Martindale. Shakespeare and the Uses of Antiquity: An Introductory Essay. London: Routledge, 1990. Print.

Miles, Geoffrey. Shakespeare and the Constant Romans. Oxford: Clarendon Press, 1996. Print.

Miola, Robert S. Shakespeare's Rome. Cambridge: Cambridge University Press, 1983. Print.

Parker, Barbara L. Plato's Republic and Shakespeare's Rome: A Political Study of the Roman Works. Newark: University of Delaware Press, 2004. Print.

Pennacchia, Maddalena. Shakespeare intermediale. I drammi romani. Spoleto: Editoria \& Spettacolo, 2012. Print.

Platt, Michael. Rome and Romans according to Shakespeare. Salzburg: Institut für Englische Sprache und Literatur, 1976. Print.

Siegel, Paul N. Shakespeare's English and Roman History Plays: A Marxist Approach. Rutherford: Fairleigh Dickinson University Press, 1986. Print.

Simmons, J.L. Shakespeare's Pagan Worlds: The Roman Tragedies. Hassocks: Harvester, 1974. Print.

Spencer, T.J.B. "Shakespeare and the Elizabethan Romans." Shakespeare Survey 10 (1957): 27-38. Print.

Starks-Estes, Lisa S. Violence, Trauma and Virtus in Shakespeare's Roman Poems and Plays: Transforming Ovid. Basingstoke: Palgrave Macmillan, 2014. Print.

Thomas, Vivian. Shakespeare's Roman Worlds. London: Routledge, 1989. Print.

Traversi, Derek. Shakespeare: The Roman Plays. Stanford: Stanford University Press, 1963. Print.

Wells, Charles. The Wide Arch: Roman Values in Shakespeare. New York: St. Martin's, 1992. Print.

Wilders, John. The Lost Garden: A View of Shakespeare's English and Roman History Plays. Basingstoke: Macmillan, 1978. Print. 